\title{
Remedy as of Right for Consumer Protection
}

\section{Ong Tze Chin ${ }^{1}$}

\section{Sakina Shaik Ahmad Yusoff2}

\author{
${ }^{1} P h D$ Student, Faculty of Law, Universiti Kebangsaan Malaysia; tzechin81@yahoo.com \\ ${ }^{2}$ Associate Professor, Faculty of Law, Universiti Kebangsaan Malaysia; kinasay@ukm.my
}

\section{Doi:10.5901/mjss.2016.v7n2p142}

\section{Abstract}

\begin{abstract}
The scope and meaning of remedies are very wide and almost every legal question could be posed in terms of remedies. Remedy is used to redress or prevent a right which is legally recognised hence remedy is the means by which a right is enforced or by which the violation of a right is prevented or compensated. In the law of contract, remedies are often linked with rights, whereby in breach of contract, damages are available as a matter of right. Rights and remedies are intertwined, the right derives from the remedy and as a matter of sequence the remedy precedes the right. Consequently, the absence of a remedy points to the non-existence of a legal right. In Malaysia, the advocacy of the consumer rights effected the government to enact Consumer Protection Act 1999 (CPA1999) which aims to provide a comprehensive scheme of protection for consumers. However, the CPA 1999 failed to recognise that in order to establish the rights of consumer, its remedies shall be sufficiently redress the consumers in time of breach. Regrettably, the CPA 1999 does not provide sufficient statutory remedies for consumers. Besides the CPA 1999, the Acts that govern the consumer sales of goods contracts include the Contract Act 1950 (CA 1950) and the Sales of Goods Act 1957 (SOGA 1957) which caused many problems in the remedies of consumer sales of goods contracts. This article critically analysed the problems underlying the statutory provisions in Malaysia that governing the contractual remedies of consumer sales of goods contracts. By adopting pure legal research methodology, this article analysed the relationship between right and remedies in the scope of consumer protection. The statutory provisions governing consumer sales of goods remedies will be critically evaluated in order to highlight the insufficiency of the contractual remedies for sales of goods contracts in Malaysia.
\end{abstract}

Keywords: rights, remedies, consumer, sales of goods, contract.

\section{Introduction}

The evolution of globalisation which characterized by the liberalisation of capital movements, the deregulation of major financial markets and the spread of neo-liberal beliefs in the merits of open and competitive trade have changed the world social economy. (Raymond K.H. Chan, 2004) The changes of world social economy have since created various adverse effects and implications to the social welfare especially to the welfare of the consumers. Nowadays, consumers are no longer the major influential group which control the market economy conversely they are the weakest parties in the consumer transactions. With the market commercial forces, globalisation that promotes economy efficiency, economy growth and commercial gains have forgone ethical trading among the traders. Hence, consumer rights are being abuse and taken advantage of by the unethical traders which resulted lack of bargaining power or with no bargaining power at all in the consumer transactions. Furthermore, with the advancement of the information technology and technology communications, it has not just change the environment of consumer transactions but also posed potential risks that affected the consumers' right as a whole.

Trade liberalisation direct and indirectly affected the changes of government policies of the countries, especially in the developing countries. Greater integration and convergence of global trade into the national economies have inserted uncertainties and risks to the domestic policies and goals (Linda Low, 2003). These effects have force the developing countries to adjust their countries' policies which based on the concept of social welfare protection to the concept of trade liberalisation so as to remain competitive in the global economies. To further liberlise trade, investment agreements and organisations have since developed. For example, ASEAN Free Trade Area establishes in January 2002 which promotes trade, eliminates tariff and non-tariff barriers and consolidates and rationalises production functions in the ASEAN region. Co-operation among the region in investments with the establishment of ASEAN Investment Area in January 2003 are to increase FDI and to support regional integration (UNCTAD, World Investment Report 2003).

In line with the ASEAN Vision 2020, to transform ASEAN into a stable, prosperous, and highly competitive region 
with equitable economic development, and reduce poverty and socio-economic disparities, ASEAN Economic Community was established in October 2003 (ASEAN Economic Community Blueprint, 2008). Besides that, ASEAN Security Community and the ASEAN Socio-Cultural Community are the other two integral pillars of the envisaged ASEAN Community. In order to realize the goal of economic integration, ASEAN Economic Community Blueprint was adopted in November 2007 (ASEAN Economic Community Blueprint, 2008) Among others, Clause B2 paragraph 42, on consumer protection is aim to build an integrated economic region with a people-centered approach. The actions are to strengthen consumer protection in ASEAN through the establishment of the ASEAN Coordinating Committee on Consumer Protection (ACCCP); to establish a network of consumer protection agencies to facilitate information sharing and exchange; and to organise regional training courses for consumer protection officials and consumer leaders in preparation for an integrated ASEAN market (ASEAN Economic Community Blueprint, 2008).

ASEAN countries have different degrees of openness to the globalisation and integration in the global market economy. Despite the differences, the culture of not to involve in the domestic policies of the countries have weaken the social welfare protection especially for consumer protection in the region. Consumer protection in the ASEAN countries remain fundamentally weak and further squeezed by the economic need to be internationally competitive has affected consumer rights in consumer transaction. The relationship between the consumer and the supplier in consumer transaction is economically imbalance in favour of the supplier (Geraint Howells \& Stephen Weatherill, 2005). The supplier has the large resources to know the products and its relevant information. Consumer is more often left with limited or no information in regards to the products. More often or not, the contract was contracted on the basic of standard-form contracts, which the consumer will never or ever read the contract. With the absence of effective negotiation and agreement, remedies for consumer contract are the only tool that available to redress the consumer for such imbalance in term of breach.

\section{Right and Remedy}

In law of contract, remedies are often linked with rights, whereby in breach of contract, damages are available as a matter of right. Rights and remedies are intertwined, for Daniel Friedmann (2005), the right derives from the remedy and as a matter of sequence the remedy precedes the right. Consequently, the absence of a remedy points to the non-existence of a legal right. Before this article addresses the issue of the insufficiency of contractual remedies in the law of consumer protection in Malaysia, it is worth to discuss the theories and concepts of rights and remedies by some of the experts in this area.

For Daniel Friedmann (2005), the relations of rights and remedies are subtle and complex. For him, the type of remedy available should shed light upon the nature of the right involved. He further identified the four models that explain the rights-remedies relation, which are the primacy of the remedy model, the primacy of the right model, the unity of the right-remedy model and the 'acoustic separation' model. For the first model, the right derives from the remedy and as a matter of sequence the remedy precedes the right. Similarly, the absence of a remedy points to the non-existence of a legal right. For the second model, remedies are merely derivative and follow from the legal rights. Legal rights have an independent existence and it is possible to conceive of legal rights unsupported by legal remedies. As for the third model, the unity of the right-remedy model, which remedy constitutes an integral part of the legal right. The remedy available for its protection, its potency or weakness or even the lack of any effective remedy is simply one of the many attributes of the legal right. For his last model, the 'acoustic separation' model, which was developed by Dan-Cohen (1984) based on the separatist view of conduct rules and decision rules. Besides that, Daniel Friedmann (2005) also mentioned that certainty in the area of remedies in civil law in much less significant as compare to the criminal law. The built-in flexibility of the civil law remedies make prediction of the precise result extremely difficult. Therefore, the statutory remedies that wish to be codified and achieved certainty have to be very careful in its application and practicability.

However, for Peter Birks (2000), he categorised the connection of rights and remedies in five senses by using Blackstone and Austin theories in his article titled Rights, Wrongs and Remedies. He mentioned that remedy is an action, cause of action or the law's configuration of the action ability of a claimant's story in his first category. He further recognised that remedy is a right born of a wrong. The right is a remedy and it is remedial right. (Peter Birks, 2000) $\mathrm{He}$ codes from John Austin (1869) that:

"Acts, forbearances, and omissions which are violations of rights or duties, are styled delicts, injuries, or offences. Rights and duties which are the consequences of delicts are sanctioning (or preventive) and remedial (or reparative)."

Peter Birks (2000) theory of remedy as a right born of a grievance or injustice, he stated that in this sense those 
who believe in that monopoly will have no room for remedy. He further explains that a narrower and non-exclusive definition of a civil wrong will leave room for causation event which is no wrongs by using the example of the right to recover a mistaken payment (Peter Birks, 2000). His fourth category is that remedy as a right born of the order or judgment of a court that the judgment generated a right but also that the judgment was obtained as a matter of right. His last category was that remedy as a right born of a court's order issued on a discretionary basis. For the fifth category he stated that if the court regards its order as strongly discretionary, its content cannot reflect an interior right. The discretion which is interposed between the plaintiff and the order shows that he has no right to that which he wants ordered (Beatson, 1988). Peter Birks (2000) second, third and fourth theories of remedy all describe rights but not the first and the fifth theories.

On the other hand, Kit Baker (1998) who analysed remedies to understand rights stated that rights bear upon remedies and remedies bear upon our understanding of rights. However, he insists on creating a clean contrast between remedy and right. He says that:

"Primary rights describe a person's initial legal entitlement. Secondary rights describe the remedies to which he is entitled if the primary right is violated. When this violation takes place (for example a tort is committed or contract breached), we talk of there being injustice and a legal cause of action. Causes of action describe those events which consist in the violation of private law rights, or, to use different words of my own, primary injustices. Remedies constitute the law's response to such events and describe a secondary level of entitlement, substituted by the law for the first. Causes of action provide us with answers to the question when legal relief is to be given; remedies answer the question how it is to be given."

After considering the theories and concepts of rights and remedies, it is clear that the relationship between the both is closely related no matter how one try to depart them sophisticatedly or make a clean contrast among them. As referred to Blackstone, the wrong gave rise to the action and the action to the remedy. However, Austin thought the wrong gave rise to a remedial right and sometimes he called the right a remedy. The modern books on remedies often suggested that the wrong give rise to the remedy and that the rest is enforcement (Peter Birks, 2000).

\section{Right and Remedy for Consumer Protection}

The remedies in contract law are to facilitate commercial exchange whereby the contract was concluded based on the principle of equal bargaining power. However, for consumer who is economically weaker party in the consumer contract of sales of goods, who are often not being informed about the nature of the goods and other relevant information related to the consumer transactions. Hence the contract was concluded without bargains. The contractual remedies that inherited from the common law system is based on the doctrine of freedom to contract, on the assumption that the contracting parties have equal bargaining strength. Therefore, the general framework of the contractual remedies would not sufficiently rectify the inequality of bargaining power between the consumer and the powerful supplier. Legal intervention of consumer protection law, either by statutory or judiciary intervention, is to redress the imbalance of bargaining power of the consumer in the market economy. The fact that the consumer has legal rights confer by statute is of little compensation if there is not suitable remedy to enforcing those rights.

The common law rules of the law of contract stress upon the freedom of contract whereby the individuals are free to make whatever contract they wish on the assumption that all contracting parties have more or less equal bargaining strength (David Oughton \& John Lowry, 2000). Therefore, the principles of contract law are of general application for both the commercial and consumer contracts. Similarly, the remedies under the law of contract which merely lay down a general framework of the remedies that applicable to all the contracts, including consumer contract of sale of goods. It is obvious that the common law of remedies would not offer any protection to the consumer hence insufficiently redress the consumers. The statutory remedies in Sales of Goods Act 1957 (SOGA 1957) and Consumer Protection Act 1999 (CPA 1999) provide some form of protection to the consumers. However, these statutory remedies in the Acts appear to be rather confusing and conflicting against one another, hence failed to enforce the consumer rights accordingly. Statutory remedies of SOGA 1957 and CPA 1999 should serve the purpose of balancing the imbalance of bargaining power between the consumers and the traders so as to achieve contractual justice. As such, it should be reflected in its remedies so as to protect the consumer.

In the latin words, ubi jus ibi remedium, which means that there is a right, there is a remedy, thus right and remedy are intertwined. In order to ensure that consumer right to be sufficiently protected by the law against the unfair trade practices, remedy is the only means to ensure consumer right for redress is protected. This article wish to highlight that remedy, no matter in what form, is a right for consumer protection. In the modern market economy, the marketing of 
goods for consumer is conducted by big organisation and trained businessman who in every attempt to persuade the consumer to buy goods or enter into contract on the terms and conditions which are favourable to them. As such in time of breach of the consumer sale of goods contract, consumer is in the weakest position as compare to the large business organisation, as the terms and conditions in the contract were in such a way that it would jeopardised consumer rights in claiming against the producer or the supplier. Besides that, litigation is disproportionately costly and troublesome to the small consumer, even with the small claims tribunal, consumer was caught in between the terms that are so unfair to them in the contract entered. Therefore, only with the proper remedied scheme or system, consumer can be protected through remedy by upholding consumer rights.

\section{Insufficiency of Contractual Remedies for Consumer Sale of Goods Contract in Malaysia}

The principle of caveat emptor which means that 'let the buyer beware' has caused many unfair practices in the consumer transactions. This general rule cannot be used in the modern market economy, as the consumer is impossible to be aware of all the terms and conditions which had been sophisticatedly draft out or frame by the large business organization in the consumer transactions. Hence, consumer undoubtedly needs protection by the law, in Malaysia, the CPA 1999 came into force on $15^{\text {th }}$ November 1999 after a protracted years of struggle by the consumer movement.

The law aim to provide a comprehensive law to protect consumers and also to redress the consumers by providing a redress mechanism which is consumer friendly and capable of handling consumer claims in a speedy manner. Even with the redress mechanism in place, the CPA 1999 was short coming in its part of remedies which should be protected as of right for consumer protection. In order to improve the transparency of the bargaining process and to control the outcomes which are not deemed to be the product of proper contractual freedom, remedies for consumer protection should be functioned in such a way to protect the consumers. However, the law failed to recognise that in the event of a breach of contract, the remedies available should serve the purpose of protecting the consumer as well as redress the consumer because of the lack of contractual freedom. A more sensitive and structured remedies should be available for the consumer contracts in sales of goods. Despite the important of the appropriate remedies that sufficiently redress the consumer, the method of assessment of the appropriate remedies for breach of consumer sales of goods contract is also important to achieve certainty and predictability in its operation.

Many experts in the area have complaints that the main problem of CPA 1999 was that it is 'supplementary' in nature to other legislation. In section 2(4) of the CPA 1999 provides that:

"The application of this Act shall be supplemental in nature and without prejudice to any other law regulating contractual relations."

The literal interpretation of s. 2(4) of the CPA 1999 provides that in the situation where there is conflicts between CPA 1999 and any other legislation regulating contractual relations, those others Acts shall be given priority even though one of the parties in the contract is consumer (Sakina, 1999). Therefore in the sales of goods contract which involved other legislation such as Contract Act 1950 (CA 1950) and the SOGA 1957, the remedy of such a contract is left to the CA 1950 and SOGA 1957. This clearly hinders the effectiveness of the CPA 1999 in providing protection for consumers especially in providing proper and sufficient remedy for consumers in time of breach.

In order to ensure that consumer right is sufficiently protected, it should begin with remedy, as remedy is the only tool to sufficiently enforced consumer right. Therefore, law of consumer protection should acts as a protector to provide adequate redress to the consumer during the breach of consumer sales of goods contract. Because the linkage between the remedies and rights cannot be considered in isolation, thus remedial rules are important to ensure that consumers are being sufficiently protected under the law. This article identified the main problem in the area of remedies for consumer sales of goods contract under the law of Malaysia. The issue arises is related to the theories of remedies; the theories of the remedy affect the ways that particular remedy functions. Remedies raises important theoretical questions, for example, the different approaches to remedies taken by theories that justify contract law on the basis that it protects individual rights (rights-based theories) and theories that justify contract law on the basis that it promotes social welfare (utilitarian theories)(Stephen A. Smith, 2004). Besides that, theories were distinguished according to whether they regarded contractual obligations as created by self-imposed obligations (promissory theories), reliance inducing statements (reliance theories), or transfers of already existing rights (transfer theories) (Stephen A. Smith, 2004). Regrettably, these theories of remedies were not being proper considered under the CPA 1999.

According to Stephen A. Smith (2004), rights-based theories approach remedial issue in four stages. Firstly, the parties to perform their contractual obligations; second, to compensate the plaintiffs for any losses they suffered as a 
result of the defendant breaching their contractual duties. Third, the plaintiff to ask the courts to order defendants to return to them benefits that they conferred on those defendants in anticipation of performance. Fourth, plaintiff may request the court to punish the defendants (Stephen A. Smith, 2004). However, the idea that contract creates individual rights and that rights should be respected, do not imply any particular view about how courts should respond to claims that contractual rights have been breached. The consumer protection law approaches the remedial issue in a very different ways as compare to the contract law. The law of consumer protection which contains the underlying concepts of consumerism, consumer welfarism and also consumer protection approach remedial issue in different ways for each of the concepts. Therefore, in order to provide the proper remedies under the CPA 1999, the underlying concepts of the CPA 1999 should be first ascertain before the remedies is provided under such Act.

In Part VI of the CPA 1999 provides rights against suppliers in respect of guarantees in the supply of goods, where section 39 provides the consumer's right of redress against suppliers. Section 39 of the CPA 1999 states that:

This Part gives a consumer a right of redress against a supplier of goods where goods fail to comply with any of the implied guarantees under sections 31 to 37 .

Basically, there are four types of remedies provided under section 42(1) of the CPA 1999, namely, repairing the goods, curing any defect in title, replacing the goods and refunding of any money or other consideration to the consumer. However, in spite of this, there are exceptions to this right of redress provided under section 40 of the Act which provides that:

...there shall be no right of redress against the supplier of goods under this Act in respect of the failure of the goods to comply with the implied guarantee as to acceptable quality where -

(a) the manufacturer makes a representation in respect of the goods otherwise then by a statement on any packaging or label; and

(b) the goods would have complied with the implied guarantee as to acceptable quality if that representation had not been made.

These exceptions were unfair to the consumers because there is much room for the suppliers to escape their liabilities. The issue was that if the manufacturer makes a representation but not the supplier, the consumer would have no right of redress against the supplier. Besides that the issue of the implied guarantees as to acceptable quality under sections 32, as discuss above, CPA 1999 is of 'supplementary' in nature, the implied guarantees would fall under the section 16 of SOGA 1957 under the implied condition as to quality or fitness. In consumer sale of goods contract, where CPA 1999 and SOGA 1957 are both applicable, the intelligence supplier would definitely use the SOGA 1957 to their advantage so as to escape liabilities. Thus, no matter in what circumstances if the CPA 1999 remains 'supplementary' in nature, consumers would not be adequately redress even by providing a right to redress for the consumers.

Further, Part VII of the CPA 1999 provides rights against manufacturers in respect of guarantees in the supply of goods, and consumer's right of redress against manufacturers was provided under section 50 of the Act. Similarly, the exceptions to such right of redress are provided under section 51 which states that:

...there shall be no right of redress against the manufacturer under this Act in respect of goods which fail to comply with the implied guarantee under sections 32 or 34 where the failure is due to -

(a) an act, default or omission of, or any representation made by, a person other than the manufacturer; or

(b) a cause independent of human control, occurring after the goods have left the control of the manufacturer.

These exceptions were not in compliance with the primary objective of consumer protection which is to adequately redress the consumers. The exceptions in section 51 are to protect the manufacturer rather than provide the right to redress for consumers, hence open the floodgate for the manufacturer to escape liabilities.

Likewise in the section 52 of the CPA 1999, the remedies available for the consumer are damages, reduction of price of the goods, repairing the goods and replacing the goods. In law of contract, damages are intended to put the plaintiffs in the same position, so far as money is able, that they would have been in had their contracts been performed (L. Fuller \& W. Purdue, 1936). This approach is aim to compensate plaintiffs' expectation interest and also aim to compensate the promisee's promissory or performance interest (Daniel Friedmann, 1995). On the other hand, remedies to repair and replacing goods are based on the theories of corrective justice. Corrective justice is concerned with the justice of duties to repair or to rectify harms and in particular, with duties to repair harms caused by one's wrongful actions (S. Perry, 2000). Hence, corrective justice might thus be described as individual or personal justice. The general idea underlying corrective justice is that individuals have a duty to repair or correct wrongful losses they caused (Stephen A. Smith, 2004). As such, in the law of consumer protection, a higher degree of approaches to remedial issue should be 
used in order to act as the protector for consumers.

Despite the fact that the underlying doctrines of consumer protection law influence the function of the remedies, the remedies provided under the CPA 1999 were not based on any theories of the remedies or the underlying doctrines of consumer protection law as discuss above, therefore, it does not justify the choice and the used of the remedies under the Act. Hence, it would cause uncertainty and ambiguity in its application. The consumer claims are under the jurisdiction of the Tribunals for Consumer Claims (Part XII of the CPA 1999), whereby there is no judicial interpretation of the justification of the remedies awarded unless the claim was brought over for judicial review in the court. The lack of judicial interpretation on the justification of remedies under the Act, there is little of the binding effect or enforcement for such remedies. Consumers would also find it rather hard to predict the remedies that might be awarded, it is all left to the discretion of the Tribunals. As such, it would affect the consumers' confidence in referring the claims to the Tribunals thus raise the issue of the reliability of the Tribunals. As a result of that, consumer claims were not being referred and the sophisticated and well drafted piece of legislation would seems to defeat its purpose in providing a comprehensive law of consumer protection. Without due considerations of the theories of the remedies, the rights of redress could not be upheld so as to serve the true function and purpose of the remedies.

As discuss above, because of the 'supplementary' nature of the CPA 1999, in consumer contract of sale of goods which involved consumer and the contract of sale, CA 1950 and SOGA 1957 would prevail hence the remedies available are the general contract law remedies rather than the remedies under the CPA 1999. Notwithstanding that, section 52 further provides that:

\footnotetext{
...no action shall be commenced under paragraph (1)(a) unless the consumer has required the manufacturer to remedy the failure and the manufacturer has refused or neglected to remedy, or has no succeeded in remedying, the failure within a reasonable time.
}

It is clear that section 52 is not meant to protect the consumers in its full senses which fail to redress the consumers adequately. Without the proper consideration of the doctrines underlying the consumer protection law and the contractual remedies, any remedies or rights that tried to act as a protector for consumers would not adequately redress the consumer and upheld the objectives of the consumer protection law. Therefore, a more sensitive and structure of the contractual remedies which govern the consumer sale of goods contract should be in place together with the consumer protection law so as to fill the lacuna of the law of remedies in providing consumer protection.

\section{Conclusion}

Among others, the objectives of consumer protection law are to remedy the market failure which is to regulate or intervene in the market in order to put the consumer into a better position than he or she would be in without the regulation or the interventionist function; and also to provide redress to consumers. The law of consumer protection fails in many ways to achieve the objectives hence CPA 1999 fails to provide adequate remedies for consumer contract of sale of goods. The remedies for the consumer sale of goods contract are still left in the faith of the general principles of the contract law. The decline of a common set of the contract law principles has forced the development of the consumer protection law and without an effective piece of legislations, consumer protection law cannot functions effectively to provide appropriate consumer redress. As such, it is time that the law of remedies to move forward in-line with the consumer protection law so as to offer a complete regime of law in consumer protection.

The development of consumer protection law in Malaysia is to further improve and adjust the transparency of the bargaining process between consumers and the traders in order to control the consumer contracts which concluded without the freedom of contract. The consumer contracts which are concluded without equal bargaining power or arbitrary directly infringe the consumer rights especially the right to redress. During the breach of such arbitrary consumer contracts, consumer can only be redress with the contractual remedies that available under the law of contract. Theories and concepts of consumer protection law is very important to enforce consumer rights, thus it should be included in the contractual remedies which remain the only means to redress the consumers directly. However, by recognizing the rights to redress in CPA 1999 without the true and proper consideration of the theories of contractual remedies and without the specific scheme of remedies which functions as protector to the consumers, the CPA 1999 fails to provide an adequate protection to the consumers thus fails in redress the consumers. The underlying theories of the CPA 1999 are also not clear. It is hard even for the expert in consumer protection law to identify and appreciate the underlying theories of the CPA 1999. The issue of whether the legislation is based on philosophy of consumerism or consumer welfarism or a total consumer protection are crucial so as to ensure consistency of every part of the Act. 
In a nutshell, to understand remedies is to understand the rights. In this context, the rights of consumer and the consumer rights to redress. The CPA 1999 is shortcoming in many ways in providing redress to the consumers. Unless and until the legislative appreciate the underlying theories and concepts of the law of consumer protection and the contractual remedies and its approaches, the consumers would not be adequately redress and protected in the consumer sale of goods contract.

\section{Acknowledgement}

This paper is part of the findings of the FRGS/2/2014/SSI10/UKM/02/1 research project.

\section{References}

Raymond K.H. Chan, (2004) 3 (3). An Overview: Themed Section on Globalisation and Welfare Systems in Asia. Social Policy \& Society, Cambridge Journals, Cambridge University Press, 253.

Linda Low (2003). Social protection in the "new" economy. Bulletin on Asia-Pacific Perspectives, 29

UNCTAD, World Investment Report 2003 - FDI Policies for Development: National and international perspectives (2003) New York \& Geneva: United Nation

ASEAN Economic Community Blueprint, Jakarta: ASEAN Secretariat: January 2008, ASEAN Secretariat 2008, at ASEAN Website: www.asean.org.

Geraint Howells \& Stephen Weatherill (2005). Consumer Protection Law (2nd edn), Ashgate.

Daniel Friedmann (2005). Rights and Remedies, Comparative Remedies for Breach of Contract, Hart Publishing Oxford \& Portland, Oregon.

Dan-Cohen (1984). Decision Rules and Conduct Rules: On Acoustic Separation in Criminal Law 97 Harvard Law Review 625.

Peter Birks(2000). Rights, Wrongs and Remedies, Oxford Journal of Legal Studies, Vol. 20, No. 1., pp.1-37

J. Austin (1869). Lectures in Jurisprudence (edited by R.Campbell, 3rd edn, 1869) 794-6. Bloomsbury Publishing, (2008).

Beatson (1988). Prematurity and Ripeness for Review in C. Forsyth and I. Hare (eds), The Golden Metwand and the Crooked Cord (1988).

Kit Barker (1998). Rescuing Remedialism in Unjust Enrichment Law: Why Remedies are Right, Cambridge Law Journal 57(2) (pp 301327).

David Oughton \& John Lowry (2000).Textbook on Consumer Law, 2nd edition, Blackstone Press Ltd.

Review of the Consumer Protection Act 1999 by FOMCA contributed by A.P. Dr. Sakina Shaik Ahmad Yusoff.

Stephen A. Smith (2004). McGill University, Contract Theory, Clarendon Law Series, Oxford University Press.

L. Fuller \& W. Purdue (1936). The Reliance Interest in Contract Damages, 46 Yale Law Journal 53.

D. Friedman (1995). The Performance Interest in Contract Damages, 1995, Vol III, Law Quarterly Review.

S. Perry (2000). Corrective v Distributive Justice in J. Horder Edition, Oxford Essays in Jurisprudence, th $^{\text {th }}$ Series, Oxford University Press.

Lecture notes of A.P. Dr. Sakina Shaik Ahmad Yusoff in the course of Advance Sale of Goods Law.

Brain W. Havey \& Deborah L. Parry (2000). The Law of Consumer Protection and Fair Trading, $6^{\text {th }}$ Edition, Butterworrths, London.

Malaysian Consumer Protection Act 1999.

Malaysian Sale of Goods Act 1957.

Malaysian Contract Act 1950. 